University of South Carolina

Scholar Commons

Fall 10-1-1992

\title{
Quincentennial Scholarship and the Public: Who Controls the Columbian Legacy?
}

Michael C. Scardaville

University of South Carolina - Columbia, mscardaville@sc.edu

Follow this and additional works at: https://scholarcommons.sc.edu/hist_facpub

Part of the History Commons

\section{Publication Info}

Published in Public Historian, Volume 14, Issue 4, Fall 1992, pages 102-114.

http://ucpressjournals.com/journal.asp?j=tph

(C) 1992 by University of California Press

This Book Review is brought to you by the History, Department of at Scholar Commons. It has been accepted for inclusion in Faculty Publications by an authorized administrator of Scholar Commons. For more information, please contact digres@mailbox.sc.edu. 


\title{
Quincentennial Scholarship and the Public: Who Controls the Columbian Legacy?
}

\author{
Michael C. SCARDAville
}

The Conquest of Paradise: Christoper Columbus and the Columbian Legacy by KirkPatrick Sale. New York, N.Y.: Alfred A. Knopf Publishers, Inc., 1990; $x+454$ pp., notes, source notes, index; clothbound, $\$ 24.95$.

Columbus: The Great Adventure; His Life, His Times, and His Voyage by PaOlo Emilio TAviani, translated by Luciano F. Farina and MarC A. BECKWITH. New York, N.Y.: Orion Books/Crown Publishers, 1991; vi +276 pp., bibliographic essay, index; clothbound, $\$ 20.00$.

The Mysterious History of Columbus: An Exploration of the Man, the Myth, the Legacy by JoHN NOBLE WiLfORD. New York, N.Y.: Alfred A. Knopf Publishers, Inc., 1991; 336 pp., illustrations, bibliographical notes; clothbound, $\$ 25.00$.

The Worlds of Christopher Columbus by William D. Phillips, JR. and Carla Rahn Phillips. Cambridge and New York, N.Y.: Cambridge University Press, 1992; xii + 322 pp., notes, maps, illustrations, bibliography, index; clothbound, $\$ 27.95$.

Columbus by Felipe Fernández-Armesto. Oxford and New York, N.Y.: Oxford University Press, 1991; xxviii +220 pp., maps, notes, illustrations, index; clothbound, $\$ 22.95$.

It's 1992: Let the parades begin! The 500th anniversary of Christopher Columbus's landfall in the Western Hemisphere has elicited a wide array of observances in this and many other countries around the globe. Over

Michael C. Scardaville is the director of the Latin American Studies Program at the University of South Carolina and a member of the South Carolina Columbus Quincentennial Commission. He is a former chair of the National Council on Public History. 
thirty nations and twenty states in the United States have established official quincentennial commissions to oversee and sponsor activities as diverse as flotillas, beauty pageants, essay contests, conferences, movies, television programs, operas, cruises, scholarships, research projects, and publications. The World's Fair and Olympics in Spain and even a new multimillion-dollar lighthouse in Santo Domingo are dedicated to the memory of the Great Discoverer. What has been planned worldwide for 1992 exceeds any previous commemoration of Columbus. But unlike the celebrations of 1792 and 1892, this one has its detractors, particularly groups who believe the European "discovery" and subsequent settlement of the New World should be mourned, not celebrated. Little did Columbus know that he would become the target of such praise and scorn a half millennium later. The weaver's son from Genoa has taken center stage on the world's historical scene this year.

The quincentenary provides an unprecedented opportunity to make history, both popular and scholarly, accessible to nonspecialists in many countries. The assessment of the European voyages of discovery and their impact should enable historians to reach a global audience. With the Columbus hoopla paving the way, Clio should be able to share center stage with the Great Explorer. Historians should at least be able to aim the spotlight at him.

While commemorative events typically focus public attention on some aspect of history, it does not necessarily follow that they enable people to gain any historical understanding. Such celebrations, whether local, national, or international, far too often enhance fables and myths at the expense of the historical record. Erroneous popular notions are regrettably reinforced by forces that are beyond the control of historians. The story of Columbus offers one of the best examples of the intermingling of fact and fiction. Columbian misconceptions are handed down from generation to generation. Sailors' fear of sailing off a flat earth, Columbus's depiction as a modern man fighting this and other medieval superstitions, and his rumored love affair with his benefactor, Queen Isabella of Castile, are notions that scholars have refuted over the past century, but through a variety of popular outlets as well as history textbooks, they remain part of our collective consciousness.

For the past three centuries, the real Columbus has often been obscured by symbols erected in the early years of the United States and reinforced through nineteenth-century popular biographies such as Washington Irving's A History of the Life and Voyages of Christopher Columbus, which was published in three volumes in 1828 and reprinted in English thirty-nine times by 1900 . While debunking the hero image has become fashionable, if nor politically correct, in some circles, what still remain for much of the public's consumption are simplistic, stereotypical notions of Columbus and his legacy. A legitimate concern is that the more public-oriented events of the quincentenary will reinforce, not challenge, 
such historical misunderstanding, and that Columbus, the symbol, will continue to overshadow Columbus, the person.

The written word will endure long after the parades are over, the beauty contests won, and the tall ships sail out of the harbors. More so than in the United States, scholarship was part of the Tricentennial festivities in late eighteenth-century Europe, when the Spanish government authorized a multivolume edition of documents relating to Columbus, and during the quadricentenary with the publication of additional Columbiana by the Italian Columbus Commission. ${ }^{1}$ Both historical editions have made a lasting contribution to scholarship on Columbus and other European voyagers. Not to be outdone in the late twentieth century, historians, other professionals, and amateurs have responded to the United States quincentenary by publishing a multitude of books and articles pertaining in some way to the "Encounter," the term officially endorsed by the National Endowment for the Humanities to describe the meeting of the Old and New Worlds in 1492. Recognizing the opportunities provided by occupying center stage, most authors, whether scholarly or popular, aim to reach the general audience with readable studies of Columbus. The five books under review here are typical of the Columbus publications prepared in time for the quincentennial year. In assessing Columbus and his impact, these authors include the mythmakers, the "PC" advocates, and journalists-turned-historians, as well as professional scholars reaching beyond the walls of the academy.

How does Columbus fare in 1992 with this representative group of authors? Not well in the hands of Kirkpatrick Sale, a freelance writer who has garnered much publicity with his polemical Conquest of Paradise. This revisionist version of the voyages and legacy of Columbus knocks the hero off his pedestal, and the resulting debris brings down Western civilization in the process. Sale is an environmental activist who uses the quincentenary to redefine the traditional Eurocentric view of the Discovery by drawing attention to the destruction of the peoples and lands of the New World at the hands of Western powers after 1492. The historical profession comes under attack as well, since "conventional" historians, Sale believes, have contributed to the myths that shroud Columbus and obscure the real character of the man who despoiled the world. His claim to new knowledge and insight is misleading, however, as Justin Winsor publicly detailed Columbus's failings a century ago. ${ }^{2}$ While Sale would

1. Martín Fernández de Navarrete, ed., Colección de los viajes y descubrimientos que hicieron por mar los espānoles desde fines del siglo XV, 3 vols. (Madrid: Imprenta real, 1825-1837); Cesare de Lollis, ed., Raccolta di documenti e studi pubblicati dalla Reale Commissione Colombiana del quarto centenario della scoperta dell America, 15 vols. (Rome: Ministero della pubblica istruzione, 1892-1896).

2. Justin Winsor, Christopher Columbus and How He Received and Imparted the Spirit of Discovery (Boston and New York: Houghton, Mifflin and Company, 1892). Winsor based much of his critical account on the documents gathered and published by Navarrete earlier in the century. 
like to believe he is taking on the scholars, his battle is largely with the ingrained popular images of Columbus.

According to Sale, fifteenth-century Europe, materialistic, violent, intolerant, and disease-ridden, was a sick society in need of regeneration. Europe would survive its misery only by finding other peoples to exploit. The culture that landed in the New World in 1492 needed a "means to expand to foreign shores and relief from the inbred despondency and institutional decadence to which it had for so many decades been a victim" (p. 72). Europeans, however, failed to revitalize their societies when they destroyed Paradise in the New World, an unspoiled land inhabited by pacifistic, harmonious, and nonmaterialistic peoples who embraced sound ecological values. The voyages of Columbus started the process by which "a single (Western) culture came to dominate as never before all the other cultures in the world, to impose its languages in other mouths, its clothes on their backs, its values in their hearts, and to accumulate to itself the power that now enables it to determine nothing less then the destiny of the world" (p. 27). In conquering Paradise, the West lost the opportunity to regenerate itself, although we and the planet now can be saved by rejecting materialism and embracing an organic and tribal approach to life: "There is only one way to live in America, and there can be only one way, and that is as Americans-the original Americans-for that is what the earth of America demands" (p. 369).

Sale has nothing positive to say about Columbus. The dethroned hero is portrayed as a person who is stubborn, duplicitous, moody, self-serving, and selfish. His many deceptions can be explained by a "failure to distinguish the real world from the illusory, the experienced from the imagined, which we call madness" (p. 50). Sale even questions Columbus's ability as an explorer. He is described as a "wretched mariner" (p. 209), and luck is the explanation whenever Columbus does the nautically correct thing. Sale never loses an opportunity to lessen the accomplishments and, hence, the stature of Columbus. He painstakingly notes that Columbus is not the first European discoverer of the Western Hemisphere since, in addition to the Norse explorations of the tenth century, there is "a body of strong and generally persuasive evidence" that suggests many other sightings and possibly landings in North America before 1492 (p. 70). Columbus, the working-class sailor, is also criticized for not being a well-versed naturalist able to accurately describe the unfamiliar flora and fauna of the Caribbean: "it is a disappointment nonetheless that the Great Discoverer of the New World turns out to be quite so simple, quite so inexperienced, in the ways of discovering his environment" (pp. 103-4).

Sale condemns not merely Columbus, but by extension Western culture. Columbus represents and is responsible for what Europe and the United States did to the peoples and lands of the New World. He thus becomes the symbol of exploitation and imperialism, the embodiment of Eurocentrism, racism, and oppression. Little wonder Columbus recently 
has been described by one pundit as "the deadest white male now offered for our detestation." 3

Sale's provocative view of the Encounter and aftermath is well researched and centers around historical themes and issues. Yet, I argue, it is not a historical work. It is propaganda dressed up as history. His use of history to grind an ax and not to elucidate the past does not further understanding of the discipline for his intended audience. In this work, history, politically correct or otherwise, becomes nothing more than a forum to promote a particular political agenda.

Among the book's shortcomings are a limited and distorted historical context and an improper use of evidence. Sale shows his misunderstanding of the Early Modern age by claiming that Columbus sought royal support for his journey to search for "fabled islands" in the Atlantic (p. 24). $\mathrm{He}$ tries so hard to debunk the notion that Columbus was a man with a vision that he fails to realize that Ferdinand and Isabella, pragmatists with severe financial limitations, would never have agreed to such a fanciful, yet expensive, idea. Moreover, Sale argues that the sole incentives for Columbus and "the millions who would follow him" are "God, gold, and glory," motivations which do not take the many other political, economic, and social factors into account (p. 18). Simplistic, one-sided notions of European civilization do not enhance understanding of the period and the issues.

Historical evidence is also sacrificed to support Sale's determinist views. He seldom critically assesses documentation or treats it evenhandedly, particularly the sixteenth-century account prepared by the Spanish Dominican Bartolomé de las Casas. ${ }^{4}$ Las Casas, the West's first defender of Native-American rights, provides Sale (and other supporters of the "Black Legend") with substantial ammunition to condemn Spanish treatment of the Indians. Historians of the period use Las Casas with care since he prepared his treatise to sway policy at the Spanish court and was prone to overstatement and exaggeration. Sale acknowledges that the Dominican was "a committed partisan of the Indians," but uses his descriptions uncritically since "there is no reason to doubt his accuracy, and all of what he recounts has the undisputable ring of truth to it" (pp. 155-56). He dismisses evidence depicting unattractive indigenous practices, such as cannibalism, because of the Europeans' inability to understand the cultures of the New World or their need to justify Western imperialism.

Sale is heir to the tradition of the Noble Savage in Western thought. Themes of New World communalism, social harmony, and peaceful coexistence with nature are found in Europe as early as the sixteenth century and are revived as part of the Enlightenment two centuries later.

3. Garry Wills, "Goodbye, Columbus," The New York Review of Books (November 22, 1990), 8.

4. Bartolomé de las Casas, Historia de las Indias, edited by Agustín Millares Carlo, 3 vols. (México: Fondo de Cultura Económico, 1951). 
Sale's humanistic version of a Biblical paradise in the Western Hemisphere, an idealized image of people living in harmony with their surroundings, is more imagined than real. Native-American societies did practice warfare, slavery, human sacrifice, and gender inequality, and they exploited and mismanaged the environment. They were, after all, human.

At the core of Sale's misrepresentation of the Encounter is his reluctance to place European conquest and the aftermath within the broader process of conquest that has been central to the changing nature of civilizations everywhere for thousands of years. He indicts the Europeans not merely for their conquest of the Native-American peoples, but also for their inability to learn from the vanquished. The Europeans did not "pause to observe, ... to borrow the wisdom and the ways of a foreign, heathen people" (p. 367). The West is singled out for these sins, although, regrettably, they are committed whenever one people conquers another, whether in Asia, Africa, or among the indigenous societies of the Western Hemisphere before European contact.

The Conquest of Paradise provides an intriguing look at the Columbian legacy, one that has claimed much attention in a press that feeds on sensationalism. Yet in the final analysis, this politically correct version of Columbus paints a one-dimensional and simplistic view of the past. The complex and multifaceted nature of Columbus and of European and American societies are sacrificed to a thesis bound in an intellectual straightjacket. A hero-and-villain approach to history does nothing to further historical understanding. In undermining the legendary view of Columbus, Sale creates another, and equally unsatisfying, mythological version of the Encounter and its effects.

The idealized Columbus, the historical figure with an exalted reputation, is represented in Columbus: The Great Adventure by Italian historian and politician Paolo Emilio Taviani. In composing a twentiethcentury hagiography, he, like his mentor, Samuel Eliot Morison, is one in a long line of Columbian eulogists. ${ }^{5}$ This publication is a condensed edition of Taviani's four-volume scholarly study of Columbus and is intended to make the Great Discoverer more accessible to the general reader. ${ }^{6}$

Taviani presents a log-cabin, Eurocentric view of Columbus. He paints Columbus as an intelligent and imaginative boy who rose from humble origins to become the greatest explorer in history and a catalyst for historical change. His plan to sail west to the Orient was "original and brilliant," an idea "born from inspiration" without the assistance of such learned men

5. Taviani calls Morison's Admiral of the Ocean Sea (Boston: Little, Brown and Company, 1942) the "best biography [of Columbus] in English" (p. 265).

6. Cristoforo Colombo: la genesi della grande scoperta, 2 vols. (Novara, Italy: Istituto Geografico de Agostini, third edition, 1988); I Viaggi di Colombo: la grande scoperta, 2 vols. (Novara, Italy: Istituto Geografico de Agostini, 1984). The English version of the first work was published as Christopher Columbus: The Grand Design (London: Orbis, 1985). 
as Paolo dal Pozzo Toscanelli, the Florentine intellectual who proposed a similar notion almost two decades before the initial Columbus voyage (pp. $42,49)$. The resulting Encounter not merely ushered in the modern age, it also "integrated the American continents into the Greco-RomanChristian-European culture" (p. 260).

Taviani unapologetically fosters the larger-than-life version of Columbus. Confusing strong personality traits with greatness, he believes that "Columbus is worthy of myth, for his maritime genius, his fanatic stubbornness, his faith, his charm and for the colossal undertaking that he brought to a successful conclusion" (p. 68). Taviani attributes to Columbus a "superhuman character" and "a brilliant (intuition) even in its errors" (pp. 7, 69). As if that were not sufficient, Columbus possesses other extraordinary gifts, including an "exceptional sense of smell" which enabled him to sense winds and currents (p. 13). This is truly an Olympian figure who stands far above his contemporaries, with perhaps the exception of other major figures of the Italian Renaissance. According to Taviani, Columbus "symbolizes the creative genius of Italy" which shaped the beginning of the modern era (p. 263).

Although he succumbs to Italian boosterism, Taviani does not believe he creates a mythological view of Columbus since he, unlike other historians who "attribute to Columbus all virtues while denying him the least defect," is willing to acknowledge that the hero is no saint (p. 98). Columbus's limitations are duly noted, particularly his mistreatment of the Indians and mismanagement of colonial affairs in the Caribbean. The Columbus that finally emerges is a complex individual, full of contradictions, but still deserving of praise and veneration.

Still, Taviani, a modern admirer of Columbus, does not offer a detached assessment of the man and his accomplishments. The result is an antiquated, romantic account compromised by a limited historical context and an abuse of historical evidence. Through the images created, Columbus: The Great Adventure is reminiscent of a textbook rendition of a popular hero. We find the youthful Columbus "dreaming of the horizon ... . dreaming of the day when he will finally reach it" (p. 6). Several love affairs do not stand in the way of his "unquenchable passion" to sail westward, although the mother of his illegitimate son stood by her man when he was initially rejected by the Spanish sovereigns, "the moment of his greatest discomfiture" (p. 70).

Taviani provides insufficient context to understand the issues, preferring instead to focus on the character of Columbus, an approach that elevates the man above his era. The misuse of historical evidence likewise contributes to the pervasive iconolatry. Taviani uncritically relies on the biography produced by Columbus's son, Ferdinand, a sixteenth-century homage that helped to create the Columbian legend. A telling statement about Taviani's methodology is his claim that hypotheses "cannot be ruled out even if there is no documentation to support" them (p. 30). Under this 
rubric, he draws a number of conclusions, such as his assertion that Columbus learned of the New World on an alleged voyage to Iceland, based not on evidence, but on speculation and conviction. Taviani seems to confuse readability with novelistic license.

This history as hero worship suffers from a severe conceptual problem. If one heaps praise on Columbus for his accomplishments and positive contributions, then one also must place the blame on him for the negative consequences arising from the Encounter. But Taviani, limited by his nationalism and unaware of his contradictions, is not willing to be evenhanded in assigning praise or blame. Whenever a black mark appears on the Columbian slate, such as the enslavement of the Indians, Taviani explains it by describing Columbus as someone typical of his era: "Columbus lived in his own time, was a man of his own time, thinking like the leaders and others of his time" (p. 103). Taviani is hard-pressed to be consistent in assessing his protagonist.

History as mythology, whether written by an advocate like Taviani or a debunker like Sale, is not good history. In these two cases, the past is abused to further either a nationalistic or ecological agenda, and the public once again fails to fully understand the past and its meaning for us today.

A more successful popular study of Columbus has been written by John Noble Wilford, the Pulitzer Prize-winning science correspondent for The New York Times. While researching a piece on underwater archaeology, Wilford became intrigued with the public's general ignorance of Columbus. Since we know so little about his ships, Wilford wondered what else we did not know, and "soon learned how long is this list of uncertainties" (p. xi). The resulting book, The Mysterious History of Columbus, explores the "Columbian mysteries," that is, historical issues which historians and others have debated since the Encounter. Wilford pays particular attention to how this information about Columbus has been generated as well as to the changing reputation of the Great Explorer over the centuries. His ultimate objective is to make these topics understandable to the public and guide the "readers who are sure to be overwhelmed during the Columbian Quincentennial with a puzzling mix of interpretation, hypothesis, and both popular and scholarly rehearsals of every imaginable aspect of the man and his discoveries" (p. xii).

What emerges from this synthesis of historical knowledge is a Columbus without the myths, a person who represents the best and worst of humanity. Wilford portrays Columbus as a mariner of great skill and intuition who is courageous, pious, bold, ambitious, charismatic, and proud, as well as overly optimistic, disingenuous, vain, prone to mistakes, and orthodox in thought. He was both a gifted explorer and an errorprone imperialist. His uniqueness was not in inventing the notion of sailing west to the Orient, but in his obsession and persistence in following his beliefs. He was a man of his time, but an extraordinary man whose determination and enthusiasm deservedly "secured for him an exalted 
place in history" (p. 64). Ultimately Columbus is a tragic yet complex figure, a product of medieval mysticism and spirituality and of modern rationalism and innovation.

In addition to creating this balanced composite of the man, Wilford ably explores the legacy of Columbus and his reputation in history. He views the Encounter as part of a larger historical process. By establishing contact between two worlds, "Columbus . . . set in motion the forces that brought about the reunion of separate strands of the human race and the virtual reuniting of the continents" (pp. 145-46). Wilford's most insightful idea, and the only original contribution in the book, is his linking of the changing image of Columbus to that of the United States. Columbus's reputation "serves as a barometer of our self-confidence and complacency, our hopes and aspirations, our faith in progress and the capacity of humans to create a more just society" (p. 259). Wilford notes the connection between the high praise of Columbus in 1892 and the rising aspirations of a confident country at that time. A century later, however, "Columbus's reputation has suffered. So has America's self-image" (p. 271). In an implied attack on Sale, Wilford chides those who use Columbus to condemn the West. Instead, he argues, the quincentenary should provide an opportunity to reexamine the global effects, both positive and negative, of the voyages of Columbus. While he agrees that an approach which celebrates the Encounter perpetuates a heroic view which "ignores the terrible toll," Wilford opines that the Encounter should not be solely measured in terms of Columbus's shortcomings or consequences to the peoples and lands of the New World (p. 275). He wonders if Columbus has borne too much of the burden: "It must be remembered who he was-not who we wish he had been" (p. 275).

Wilford has compiled a highly readable, well-balanced overview of the issues raised about Columbus and his legacy. For instance, European mistreatment of the Indians is detailed, but so is Spain's grappling with the moral dilemma that resulted. Most laudable is Wilford's effort to make the historical process understandable to the public. He tells the reader that "history is not only what happened long ago but it is also the perception by succeeding generations of those events and those people," and accordingly, historical works are "interim reports" on the past since they represent changing views on what happened (pp. xii-xiii). He illustrates how history is written by discussing evidence and interpretation surrounding most of the Columbian issues. He notes that the history of Columbus is "frustratingly incomplete" due to ambiguous and conflicting documentation as well as a lack of sources. This, he tells his readers, makes truth a slippery notion since "serious historians can honestly arrive at widely differing interpretations of motives and actions" (pp. x, 17). Few professional historians have been so clear in presenting to a nonspecialist audience these key principles of the historical method.

These kudos notwithstanding, Wilford is not always successful in meeting the stated objectives of his book. A variety of shortcomings belie his 
understanding of history. His unfamiliarity with primary material and an uncritical rendition of such sources are demonstrated by an inaccurate assessment of original documents. For instance, he treats the Las Casas transcription of Columbus's first voyage as a firsthand account written by Columbus himself. Succumbing to popular notions of history is another of the book's serious deficiencies. As evidenced by the title and approach, Wilford creates the general impression that Columbus is a mysterious figure, a person who has an undocumented past and who therefore must be recreated with conjecture and speculation. On the contrary, historians know a great deal about this humble sailor from five centuries ago. Many of Wilford's so-called mysteries can be labeled historical minutia, like the site of the landfall, which even the author admits "has little bearing on history or our assessment of Columbus" and is "usually raised only as curiosity" (pp. 127, 191). Most unfortunate is the inclusion of undocumented and suspect Columbian tales, such as a pre-1492 voyage to the New World by an "anonymous" sailor, Columbus's knowledge of the Norse voyages when in Iceland, and various (and ludicrous) statements supposedly made by historical figures. Wilford compromises what could have been a more serious effort by falling prey to these pitfalls of popular history.

In all, The Mysterious History of Columbus lacks full insight into the historical issues and the practice of history. A summary rendition of the material does fill a need, especially when measured against the mythological versions of Columbus, but this consensus approach to the issues, in which all reasonable sides are presented but few conclusions are drawn, does not represent a needed rigorous handling of the conflicting materials and interpretations. Wilford is adept at making scholarship available to the public, even if he at times succumbs to romantic and popular notions. He provides little new insight, however, into the multiple and complex issues arising from the quincentenary.

Several analytical, yet measured and comprehensive works have been written by widely respected scholars of Iberian and Early Modern European history who are attempting to reach a wide audience. William D. Phillips, Jr. and Carla Rahn Phillips, authors of The Worlds of Christopher Columbus, are professors of history at the University of Minnesota, and Felipe Fernández-Armesto, author of Columbus, is director of the Oxford Colonial History Project and general editor of The Times Atlas of World Exploration..$^{7}$ All three authors express their displeasure with un-

7. For a sample of their publications, see William D. Phillips, Jr., Slavery from Roman Times to the Early Transatlantic Trade (Minneapolis: University of Minnesota Press, 1985); Carla Rahn Phillips, Six Galleons for the King of Spain: Imperial Defense in the Early Seventeenth Century (Baltimore: Johns Hopkins University Press, 1986); Felipe FernándezArmesto, Before Columbus: Exploration and Colonization from the Mediterranean to the Atlantic, 1229-1492 (Philadelphia: University of Pennsylvania Press, 1987); The Canary Islands after the Conquest: The Making of a Colonial Society in the Early Sixteenth Century (Oxford: Oxford University Press, 1982). 
professional accounts of Columbus that have proliferated in bookstands in anticipation of the 1992 commemoration. Fernández-Armesto, not one to mince words, laments that readers have been badly misled by "many wellmeaning amateurs" (p. vii). These three Columbian scholars contend that such popular and journalistic accounts, composed by nonspecialists who lack historical knowledge of the period and who do not understand the difference between persuasive rhetoric and persuasive scholarly argument, suffer from improper use and presentation of evidence as well as an uncontrolled imagination. And as noted by the Phillipses, even "serious historians have succumbed to the heroic Columbus" (p. 7). Their concern is that the legacy of the quincentenary will be negative and that the real Columbus will still be obscured, either by legendary accounts or revisionist political activism.

The historical profession is not spared the criticism of these three authors, who note that scholars have been remiss in not presenting their expertise about Columbus to a public nurtured on simplistic and often erroneous notions of the man. This aloofness has enabled popular authors and journalists to fill the resulting vacuum. These two books are a response to the call for professional historians to offer their "best evidence about Columbus and his worlds to a broad reading public" (Phillips and Phillips, p. 17). To their credit, Cambridge and Oxford University presses, the epitome of academic scholarship, have targeted the nonspecialist audience for their quincentennial initiatives.

Both Columbus and The Worlds of Christopher Columbus are similar in purpose, although their approaches differ in key respects. The Phillipses aim to "present a balanced view of Columbus's life and times, firmly based on the historical record and firmly placed in proper context" (p. 11). Unique among the other works on Columbus is their emphasis on context. They dedicate almost half of the narrative to a review of the state, not just of Europe, but of the world on the eve of the 1492 voyage. In the process, they provide ample background to best understand Columbus and the consequences of his undertaking, most notably the "irreversible process that linked the once [fragmented] world together" (p. iii). The Phillipses conclude in a masterful chapter on the post-Columbian world that the Great Discoverer "placed the world on the path leading toward global interdependence, with enormous consequences-both good and ill-for the peoples of the world" (p. 241). The reader leaves this book with clear insight into the forces that have created an increasingly interconnected planet.

Fernández-Armesto's objective was to write a book based "on the belief that readers want unadorned facts about Columbus, as far as they can be elicited" in order "to satisfy [those] who want to make their own choices from within the range of genuine possibilities" (pp. vii-viii). While he believes context is essential for providing a broader understanding of the era, it plays a significantly smaller role than in the Phillipses' account. The 
major focus for Fernández-Armesto is the mind of Columbus, his mental world. Context is offered mainly to understand his intellectual formation.

The two books share similar perspectives on most major issues, and both provide a sound overview of Columbian historiography, replete with its "misconceptions," "silly theories," and "undisciplined speculations," to prepare the reader for the story of Columbus (Fernández-Armesto, p. vii). In addition, the three authors address the need to treat Columbus as a human being, not a hero, in order to demystify the Columbian legend. Myths, such as an indigenous paradise, are rejected by offering evidence. The "romantic veneer" of legendary histories is stripped away by calling various stories "fabrications" and proving it (Phillips and Phillips, pp. 114-15).

The Phillipses and Fernández-Armesto come down hard on Columbus, pointing out his many limitations, but placing his ideas and behavior within the context of the period. Columbus is a multifaceted individual, a human figure with vices as well as virtues. His extraordinary personal and nautical gifts, perseverance, charisma, and conviction enabled him to successfully undertake the voyages, although political ineptness and fear of failure ultimately led to disillusionment and defeat at the Spanish court. As the Phillipses succinctly note, "Columbus's enterprise of the Indies, so long in the planning, would quickly outgrow his abilities" (p. 186).

Nor is Columbus viewed as an innovator by the three scholars. His notion of sailing west grew slowly and was shared by others in Europe at that time, most notably Toscanelli. His innovation, then, was in combining existing knowledge with the firm conviction that he could carry it off. This, according to the scholars, is what made Columbus unique, for "someone else would have taken that step (of sailing across the Atlantic), even if Columbus had never lived" (Phillips and Phillips, p. 242). This demythologized view of Columbus places him as a representative figure of his era. He had no unique vision; he was not a genius, not a "lonely man of destiny, who struggled against prevailing orthodoxy to realize a dream that was ahead of its time" (Fernández-Armesto, p. 21). Yet his fame is earned, deservedly so the authors contend, primarily because of his perseverance and for being in the right place at the right time.

The Phillipses and Fernández-Armesto render excellent accounts which, through primary research, offer refreshing insights into Columbus and his legacy. Both place him squarely within the context of his time, making him and his actions understandable against a backdrop of emerging capitalism, changing religious attitudes, and expanding royal power. Both frequently discuss the authenticity and reliability of sources and point out to the reader the need to corroborate Columbus's own writings either through other authors or the historical context. An important difference between the two works is that the Phillipses undertake a more in-depth critical assessment of the evidence and carefully take the reader through the original and secondary literature on the key issues, thereby offering a number of lessons in historical analysis. 
For this and other reasons, the Phillipses are more successful than Fernández-Armesto in reaching the broader public. Theirs is a more complete account of the times, events, attitudes, and consequences while Fernández-Armesto's approach is not as broadly based nor as well written. An occasionally impenetrable writing style compromises his effort to speak to a nonspecialist audience. The Phillipses are to be commended for doing what so few professional historians have successfully done, publishing a work that can serve as a case study of the historical method for both an academic and a popular audience.

The Columbian celebrations of a century ago reinforced in popular circles the heroic image of Columbus, in spite of the emerging critical scholarship which afforded a more realistic view of the man and his accomplishments. Will the legacy of the 1992 commemoration share a similar fate? Quincentenary publications, a collection of both scholarly and more popular works, once again send a mixed message regarding Columbus and his legacy. Will the more scholarly endeavors finally undermine the mythological images of Columbus as hero or villain and become integrated into the popular historical consciousness? Which view of the Columbian legacy will come to dominate the historical stage this year and beyond? Such questions are germane to the role and influence of the historical profession in American society. Do we as historians have any impact on anyone but ourselves? Is it the historians or the popular mythmakers who play the more crucial role in shaping an understanding of the past among the public? Often those who assault history as mythology come under attack by those who use history for political and other purposes. To the cheers of the crowd at Columbus Day ceremonies in 1892, Chauncey Depew, the President of the New York Railroad, chastised scholars who depicted a Columbus with feet of clay: "If there is anything which I detest more than another it is that spirit of critical historical inquiry which doubts everything; that modern spirit which destroys all the illusions and all the heroes which have been the inspiration of patriotism through all the centuries." 8 Juxtaposed with more recent criticisms of a "cultural elite," these views suggest that ventures beyond the walls of the academy may not be so readily embraced, however sound the methodology or noble the intent.

8. As quoted in Wilford, p. 255. 